\title{
Impact of Psychological Stress on Cancer
}

\author{
Sabina Khanam* \\ Department of Biological Sciences, Yobe State University, Nigeria
}

*Corresponding author: Sabina Khanam, Department of Biological Sciences, Yobe State University, Nigeria.

Received Date: June 09, 2020

Published Date: June 19, 2020

\begin{abstract}
Psychological stress has been one of the key factor for the initiation of cancer and metastasis in body cells. Behavioural abnormalities such as chronic psychological stress, depression, anxiety and other behavioural changes have been linked to cell mediated immunity and to endocrine system consequences. The aim of this review article is to describe how psychological stress activate neuroendocrine system and tumor initiation, which leads to cancer and metastasis.
\end{abstract}

Keywords: Stress; Cancer; Endocrine

\section{Introduction}

Cancer is the second leading cause of death after cardiovascular diseases globally. Clinically and epidemiologically cancer have been related to chronic psychological stress, depression, anxiety, lack of social support and other behavioural and psychological factors. Poor apoptotic activity of the body cells, poor repair of damaged nucleic acid like DNA and RNA and abnormal exchange of chromatid may due to psychological stress. Psychological stress may affect various physiological activities of the body cells and various pathological diseases like cancer [1-5]. Immunosuppressed individuals either through immunodeficiency diseases or through pharmacological means have more risk of cancer. T-cell responses to mitogen stimulation and natural killer (NK) cell cytotoxicity are cellular immune parameters have been decrees by chronic psychological stress which leads to cancer. Psychological and behavioural abnormalities like anxiety, depression, stress leads to tumor growth, metastasis and progression [6-12].

\section{Psychological Stress and Cancer}

Some studies demonstrated that chronic psychological stress activate the hypothalamic-pituitary-adrenal axis and central sympathetic nervous system which increase the quantity of cortisol and norepinephrine(catecholamines) in the body organs which enhance the ovarian carcinoma by increasing the weight and progression of the tumor. Stress may affect carcinogenesis through changes or alterations in the DNA molecule repair and exchange of sister chromatid $[13,14]$. When all these processes do not work properly than faulty or unprepared DNA might increase the risk of cancer.

\section{Acknowledgement}

None.

\section{Conflict of Interest}

No conflict of interest.

\section{References}

1. Andersen BL, Farrar WB, Golden-Kretuz D, Kutz LA, MacCallum R, et al. (1998) Stress and immune responses after surgical treatment for regional breast cancer. J Natl Cancer Inst 90: 30-36.

2. Andersen BL, Kielcolt-Glaser JK, Glaser RA (1994) Biobehavioural model of cancer stress and disease course. Am Psychol 49: 389-404.

3. Bovbjerg DH (1991) Psychoneuroimmunology: Implications for oncology? Cancer 67: 828-832. 
4. Garssen B, Boomsma MF, Jager-Meezenbroek E, et al. (2013) Stress management training for breast cancer surgery patients. Psychooncology 22: $572-580$.

5. Spiegel D, Kato PM (1996) Psychological influences on cancer incidence and progression. Harv Rev Psychiat 4: 10-26.

6. Glaser R, MacCallum RC, Laskowski BF, Malarkey WB, Sheridan JF, et al. (2001) Evidence for a shift in the Th-1 to Th-2 cytokine response associated with chronic stress and aging. J Gerontol A Biol Sci Med Sci 56: M477-M482.

7. Lutgendorf SK, Sood AK, Anderson B, McGinn S, Maiseri H, et al. (2005) Social support, psychological distress, and natural killer cell activity in ovarian cancer. J Clin Oncol 23: 7105-7113.

8. Herberman RB, Ortaldo JR (1981) Natural killer cells: role in defences against disease. Science 214: 24-30.
9. Cohen S, Rabin B (1998) Psychologic stress, immunity, and cancer. J Natl Cancer Inst 90: 3-4.

10. Lillberg K, Verkasalo PK, Kaprio J, Teppo L, Helenius H, et al. (2003) Stressful life events and risk of breast cancer in 10,808 women, a cohort study. Am J Epidemiology 157: 415-423.

11. Reiche EM, Nunes SO, Morimoto HK (2004) Stress, depression, the immune system, and cancer. Lancet Oncol 5: 617-625.

12. Spiegel D, Giese-Davis J (2003) Depression and cancer: mechanisms and disease progression. Biol Psychiatry 54: 269-282.

13. Dhillon VS, Dhillon IK (1998) Chromosome aberrations and sister chromatid exchange studies in patients with prostrate cancer possible evidence of chromosome instability. Cancer Genet 100: 143-147.

14. Li GY, Yao KT, Glaser R (1989) Sister chromatid exchange and nasopharyngeal carcinoma. Int J Cancer 43: 613-618. 